\title{
HCV 感染と腎移植後肝機能障害に関する研究
}

\section{一全国移植施設アンケート調査一}

\begin{tabular}{|c|c|c|c|c|c|}
\hline 冨川 伸二 & 伊藤 & 生二 & 菊池 & 賢治 & 安藤 \\
\hline 直哉 & 銘形 & 和彦 & 渡辺 & 建詞 & 別宮 \\
\hline 寿一 & 長尾 & 桓 & 内田 & 久則* & \\
\hline
\end{tabular}

要 旨：HCV 感染と腎移植後肝機能障害の関連性についてアンケート調㚗を行い検討した。 腎移植後 HCV 抗体ちよび HBs 抗原の測定が行われた 1,405 例のうち, HCV 単独感染症例は 287例 (20.4\%) で, 生体腎移植群 (153/952：16.1\%)に比べ死体腎移植群 (134/453:29.6\%) で有意に HCV 感染が高率で, 両群間で透析期間, 20 単位以上輸血歴に有意差を認めた. HCV 感染症例の $47.2 \%$ に移植後慢性肝機能障害を認め，移植前に肝機能障害を認めた群では $66.7 \%$ とさらに高率であった. 多変量解析の結果から, 移植前肝機能障害, 移植後観察期間, 輸血量 の 3 要因が独立して腎移植後肝機能障害の発生に影響を及ぼす要因と考えられた。 HCV 抗体 陽性ドナーから抗体陰性レシピエントへの移植は多くの施設が否定的だったが, 抗体陽性レシ ピエントへの移植については意見が分かれた。

索引用語： C 型肝炎ウイルス 腎移植 肝機能障害

\section{A. 研究目的}

腎移植後の合併症の中で肝機能障害は感染症につい で多く，留移植成績に少なからず影響を与えている。 維持透析患者の C 型肝炎ウイルス (HCV) 感染が高率 であることから，腎移植後肝機能障害の発生に $\mathrm{HCV}$ 感染が関わっている可能性が高いと思われる。そこで, 全国規模のアンケート調查を行い, HCV 感染の有無 と腎移植後肝機能障害の関連性について検討した。

\section{B. 研究方法}

全国73の腎移植実施施設にアンケート調查用紙を郵 送し，1992年12月までに行われた腎移植症例のうち， 移植後第 2 世代 HCV 抗体括よび HBs 抗原の両者の 測定が行われた症例について回答を依頼した，調查項 目は, 両者の湘定が行われた症例数, 第 2 世代 HCV 抗 体またはHBs 抗原のいずれかが陽性であった症例に ついて，生体腎・死体腎の別，性別，移植時年齢，透 析期間, 輸血歷, 維持免疫抑制剤の種類, 移植前およ び移植後肝機能障害の有無などである.また, $\mathrm{HCV}$ 抗
体陽性者に対する腎移植実施の適否についての各施設 の方針を調査した。なお，血清 GPT 値が50IU/l 以上 が 2 週間以上持続したものを肝機能障害陽性例とし, 肝機能障害（LD： liver dysfunction）が 3 力月以内に 改善したものを一過性肝機能障害 (TLD : transient LD)， 3 力月以上遷延したものを慢性肝機能障害 (CLD : chronic LD) とした.

集団の平均値は mean $\pm \mathrm{SEM}$ で示し，各群間の有意 差検定には $\mathrm{t}$ 検定および $\chi^{2}$ 検定を用いた。また，腎移 植後肝機能障害の発生に影響を及深をと思われる因子 について多変量解析（重回㷌分析）を用いて検討した。

\section{C. 研究結果}

\section{1. アンケート調査回答施設}

以下に示す 30 施設 $(41.9 \%)$ から回答を得た.

北海道大学泌尿器科 市立札瀑病院腎移植科 東北 大学第 2 外科 筑波大学臨床医学系外科 埼玉医科大 学裁器移植センター千葉大学第 2 外科 国立佐倉病 院 東京大学医科学研究所外科・移植科 虎/門病院

Shinji Tomikawa, Seiji Ito, Kenji Kikuchi, Yuichi Ando, Naoya IchiKawa, Kazuhiko Meigata, Kenshi Watanabe, Yoshifumi Beck, Hisakazu DegaWA, Takeshi NAGAO and Hisanori UchidA*

*東京大学医科学研究所外科・移植科

$<$ 受付日1995年 6 月28日 $>$ 
分院腎センター 東邦大学腎臓学教室 北里大学泌尿 器科 東海大学移植学教空 I 金沢大学泌尿器科 浜 松医科大学泌泉器科 社会保険中京病院泌存器科 名 古屋記念病院 滋賀医科大学第 1 外科, 泌尿器科 京 都府立医科大学第 2 外科 大阪市立大学泌尿器科 国 立循環器病センター 近畿大学泌尿器科 兵庫医科大 学泌尿器科鳥取祡立中央病院広島大学第 2 外科 山口大学泌尿器科 媛大学泌尿器科 市立宇和島病 院泌尿器科 住賀県立病院好生館 長崎大学泌尿器科 国立長崎中央病院泌尿器科

\section{2. ウイルス感染と腎移植後肝機能障害}

腎移植後 HCV 抗体および HBs 抗原の両者の測定 が行われた症例は1，405例で，そのうち， $\mathrm{HCV}$ 抗体の み陽性（Ｉ群）が287例 (20.4\%)，HBs 抗原のみ陽性 （II群）が25例 (1.8\%)，両者とも陽性（III群）が 7 例 (0.5\%) であった。

腎移植前後の肝機能の推移を観察し得た症例のう ち，慢性肝機能障害を慜めた症例は I, II, III群でそ れぞれ118/250(47.2\%)，11/23(47.8\%)，5/7(71.4\%) であった。肝機能障害による死亡例はそれを゙れ4 $287(1.4 \%), 3 / 25(12.0 \%), 2 / 7(28.6 \%)$ であり, I 群で有意に死亡率が低かった（Table 1).

\section{HCV 単独陽性症例についての検討}

以下 $\mathrm{HCV}$ 単独陽性症例287例について検討した。

1) 症例の背景

$\mathrm{HCV}$ 単独陽性症例の平均年齢は33.1歳, 平均透析 期間は59.8力月，平均移䊒後観察期間は75.8力月で あった，輸血歴は，なしが30例(10.5\%)，1から19単 位が158例 (55.1\%)，20単位以上が58例 $(20.2 \%)$ ，不 明41例 (14.3\%) であった。全症例1，405例のうち生体 腎移植が952例，死体緊移植が453例であったが，それ ぞれの HCV 抗体単独陽性症例は153例 (16.1\%)，134

Table 1 Liver dysfunction in renal transplant recipients.

\begin{tabular}{|c|c|c|c|}
\hline & $\mathrm{HCV}(+)$ & $\operatorname{HBsAg}(+)$ & $\begin{array}{c}\operatorname{HCV}(+) \\
\operatorname{HBsAg}(+)\end{array}$ \\
\hline no $\mathrm{LD}^{* 2}$ & $\begin{array}{r}95 / 250 \\
(38.0 \%)\end{array}$ & $\begin{array}{c}11 / 23 \\
(47.8 \%)\end{array}$ & $\begin{array}{c}1 / 7 \\
(14.3 \%)\end{array}$ \\
\hline transient LD & $\begin{array}{r}37 / 250 \\
(14.8 \%)\end{array}$ & $\begin{array}{c}1 / 23 \\
(4.3 \%)\end{array}$ & $\begin{array}{c}1 / 7 \\
(14.3 \%)\end{array}$ \\
\hline chronic LD & $\begin{array}{l}118 / 250 \\
(47.2 \%)\end{array}$ & $\begin{array}{c}11 / 23 \\
(47.8 \%)\end{array}$ & $\begin{array}{c}5 / 7 \\
(71.4 \%)\end{array}$ \\
\hline $\begin{array}{l}\text { liver-related } \\
\text { death }\end{array}$ & $\begin{array}{r}4 / 287^{*} \\
(1.4 \%)^{*}\end{array}$ & $\begin{array}{c}3 / 25 \\
(12.0 \%)\end{array}$ & $\begin{array}{c}2 / 7 \\
(28.6 \%)\end{array}$ \\
\hline
\end{tabular}

例 $(29.6 \%$ ） と有意に死体腎移植で $\mathrm{HCV}$ 感染が高率 （p<0.01）であった。雨群間で男女比には有意差を認 めなかったが, 年齢, 透析期間, 20 単位以上輸血歴に 有意差を認めた (Table 2).

\section{2) HCV 感染と腎移植後肝機能障害}

287例のうち移植前後の肝機能障害の有無の判明し ている250例について, 腎移植前肝機能障害の有無と移 植後肝機能障害の関連について検討した.

留移植前に肝機能障害を認めた症例では36/ $54(66.7 \%)$ に移植後慢性肝機能障害を認めたのに対 して，腎移植前に肝機能障害を堙めなかった症例では $82 / 196(41.8 \%)$ に移植後慢性肝機能障害を認め，両 者の間に有意差を認めた $(\mathrm{p}<0.01)$.雨者の間で年龄, 透析期間，移植後観察期間に有意差は認められず，輸 血歴に有意差を認めた（Table 3).

\section{3）免疫抑制剂と腎移植後肝機能障害}

維持免疫抑制放 (cyclosporine：CYA, azathioprine: $A z$, mizoribine: $M z$, prednisolone: P) と移

Table 2 Characteristics of Anti-HCV-positive and HBsAg-negative recipients.

\begin{tabular}{l|c|c|c}
\hline & Living & Cadaver & \\
\hline Number of patients & 153 & 134 & \\
Age (years) & $30.3 \pm 0.7$ & $36.4 \pm 0.8$ & $\mathrm{p}<.01$ \\
Sex (\%Male) & $64.7 \%$ & $62.4 \%$ & $\mathrm{NS}$ \\
Dialysis (months) & $45.8 \pm 4.1$ & $76.6 \pm 4.2$ & $\mathrm{p}<.01$ \\
Massive transfusion* & $19.3 \%$ & $28.2 \%$ & $\mathrm{p}<.05$ \\
\hline \multicolumn{3}{c}{$\%$ more than 20 units }
\end{tabular}

Table 3 Comparison of characteristics and liver dysfunction after transplantation between patients according to liver dysfunction before transplantation.

\begin{tabular}{l|c|c|c}
\hline \multirow{2}{*}{} & \multicolumn{2}{|c|}{$\mathrm{LD}^{*}$ before $\mathrm{Tx}^{* 2}$} & \multirow{2}{*}{} \\
\cline { 2 - 3 } & $(+)$ & $(-)$ & \\
\hline Number of patients & 54 & 196 & \\
Age (years) & $33.4 \pm 1.2$ & $33.0 \pm 0.7$ & $\mathrm{NS}$ \\
Dialysis (months) & $64.7 \pm 6.4$ & $55.8 \pm 3.5$ & $\mathrm{NS}$ \\
Follow-up (months) & $71.8 \pm 6.9$ & $73.0 \pm 4.0$ & $\mathrm{NS}$ \\
Transfusion (\%) & 100 & 83.2 & $\mathrm{p}<.01$ \\
LD after Tx & & & \\
no & $7(13.0 \%)$ & $88(44.9 \%)$ & $\mathrm{p}<.01$ \\
transient & $11(20.4 \%)$ & $26(13.3 \%)$ & $\mathrm{NS}$ \\
chronic & $36(66.7 \%)$ & $82(41.8 \%)$ & $\mathrm{p}<.01$ \\
\hline \multicolumn{3}{|c}{${ }^{* \mathrm{LD}: \text { liver dysfunction }}$} \\
& *2Tx: kidney transplantation
\end{tabular}


Table 4 Maintenance immunosuppression without CYA and liver dysfunc. tion in $\mathrm{HCV}$-positive and $\mathrm{HBsAg-negative} \mathrm{patients.}$

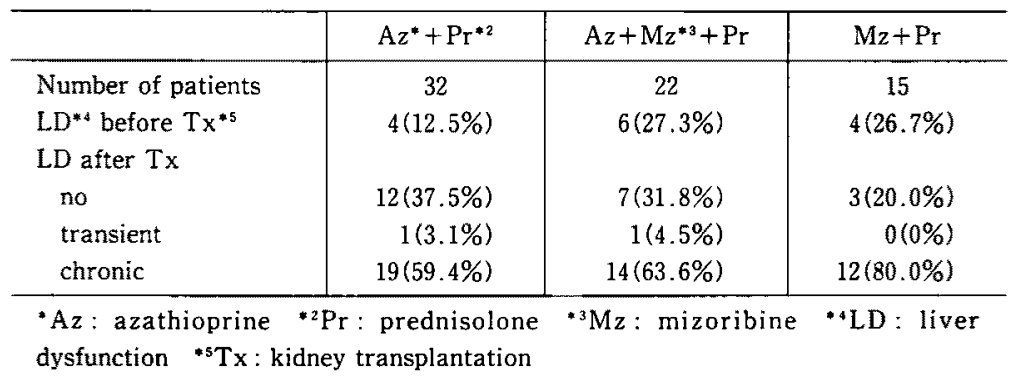

Table 5 Maintenance immunosuppression with CYA and liver dysfunction in $\mathrm{HCV}$-positive and $\mathrm{HBs} \mathrm{Ag}$-negative patients.

\begin{tabular}{l|c|c|c}
\hline & $\mathrm{CYA}^{*}+\mathrm{Az}^{* 2}+\mathrm{Pr}^{* 3}$ & $\mathrm{CYA}+\mathrm{Mz} z^{* 4}+\operatorname{Pr}$ & $\mathrm{CYA}+\mathrm{Pr}$ \\
\hline Number of patients & 73 & 57 & 33 \\
LD*s before Tx*6 & $12(16.4 \%)$ & $16(28.1 \%)$ & $8(24.2 \%)$ \\
LD after Tx & $30(41.1 \%)$ & $21(36.8 \%)$ & $12(36.4 \%)$ \\
no & $16(21.9 \%)$ & $9(15.8 \%)$ & $8(24.2 \%)$ \\
transient & $27(37.0 \%)$ & $27(47.4 \%)$ & $13(39.4 \%)$ \\
chronic &
\end{tabular}

"CYA : cyclosporine ${ }^{* 2} \mathrm{Az}:$ azathioprine ${ }^{*} \mathrm{Pr}$ : prednisolone ${ }^{* 4} \mathrm{Mz}$ : mizoribine ${ }^{*} \mathrm{LD}$ : liver dysfunction ${ }^{*} \mathrm{~T} \mathrm{~T}$ : kidney transplantation

植後肝機能障害との関連について㭘討した. Table 4 はCYA非使用例における $\mathrm{Az}$ と $\mathrm{Mz}$ の移植後肝機能 障害への影響について検討した結果である，両群間に 年齢, 透析期間, 移植後観察期間に差はなく, $\mathrm{Az}, \mathrm{Mz}$ の違いによる移植後訮機能障害の発生にも有意差は認 められなかった。 Table 5 は同様に CYA 投与群にお ける $\mathrm{Az} と \mathrm{Mz}$ の移植得畈機能障害への影響について 検討した結果である.CYA 群においでも $\mathrm{Az}, \mathrm{Mz}$ の違 いによる肝機能障害の発生には有意差はなく, CYA+ Pr群でもほ臣同様の結果であった。

免疫抑制剂をCYA 群と非 CYA 群とに分けて検討 してみると，Table 6のように非 CYA 群で有意に移 植後慢性肝機能障害が高率であった。非 CYA 群では CYA 群に比へ有意に移植後観察期間が長く, 死体腎 移植が少なかった。

4）腎移植後肝機能障害に影響を及ほす要因

腎移植後肝機能障害の発生に影響を及虫すと思われ る六つの因子（1)生体腎移植加死体腎移植の別, (2)移 植後観察期間, (3)移植前透析期間, (4)輸血量, (5) CYA 使用の有無，(6)移植前肝機能障害）について多変量解 析を行った. HCV 単独陽性症例287例中, 上記の六つ の因子のすべてについて検討し得た症例は199例て
Table 6 Maintenance immunosuppression and liver dysfunction in $\mathrm{HCV}$-positive and $\mathrm{HBsAg}$ negative patients.

\begin{tabular}{l|c|r|c}
\hline & $\mathrm{CYA}^{*}(+)$ & $\mathrm{CYA}(-)$ & \\
\hline Number of patients & 163 & 69 & \\
Age (years) & $34.0 \pm 0.7$ & $30.6 \pm 1.1$ & $\mathrm{p}<.05$ \\
Dialysis (months) & $61.9 \pm 3.7$ & $47.2 \pm 5.7$ & $\mathrm{p}<.01$ \\
Follow-up (months) & $49.7 \pm 2.5$ & $134.7 \pm 5.9$ & $\mathrm{p}<.01$ \\
LD*2 before Tx"3 & $36(22.1 \%)$ & $14(20.3 \%)$ & $\mathrm{NS}$ \\
LD after Tx & & & \\
no & $63(38.7 \%)$ & $22(31.9 \%)$ & $\mathrm{NS}$ \\
transient & $33(20.2 \%)$ & $2(2.9 \%)$ & $\mathrm{p}<.01$ \\
chronic & $67(41.1 \%)$ & $45(65.2 \%)$ & $\mathrm{p}<.01$ \\
\hline
\end{tabular}

"CYA : cyclosporine ${ }^{* 2} \mathrm{LD}$ : liver dysfunction

${ }^{*} \mathrm{~T} \mathrm{x}$ : kidney transplantation

あった，多変量解析の結果は，移植前肝幾能障害 $(\mathrm{p}=$ $0.0007)$, 移植後観察期間 $(p=0.0033)$, 輸血量 $(p=$ 0.032)の3因子が独立して腎移植後肝機能障害の発生 に影響を及ほす要因と考えられ，CYAは独立した要 因としては抽出されなかった。

5） HCV 感染者に対する腎移植の適応

移植を予定したドナーまたはレシピエントが HCV 抗体陽性の場合, 移植を行うか否か, 各移植施設の方 


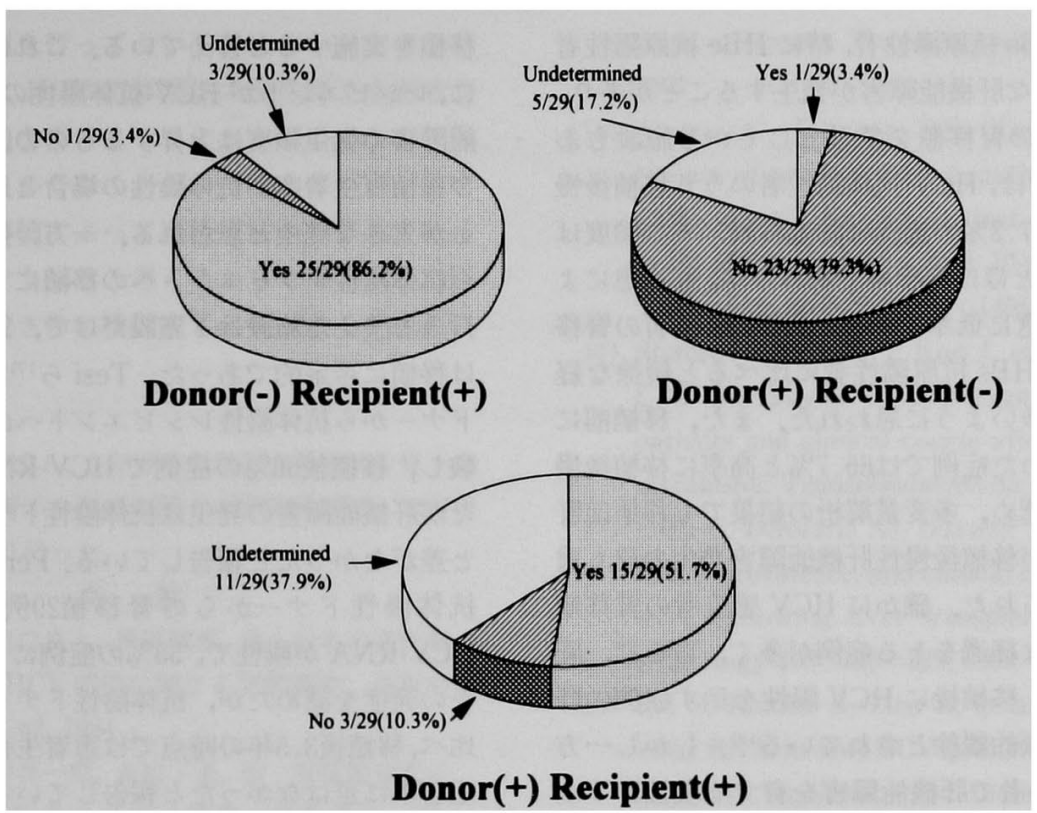

Fig. Impact of $\mathrm{HCV}$ on the practice of kidney transplantation

針を調查した.レシピエントが HCV 抗体陽性の場合， ドナーが陰性であれば移植を行うと答えた施設が25/ 29 (86.2\%) と大半を占めた。しかし，ドナーも陽性 の場合に移植を行うと答えた施設は $15 / 29$ と約半数に 留まり，他の施設は行わないか方針が未定であった。 一方, HCV 抗体陽性のドナーから陰性のレシピエン トへの移植は，行うと答えた施設は 1 施設のみて大半 の施設が行わない方針であった。(Fig. 1)

\section{D. 考 察}

1993年に行われなわが国の透析施設における HCV 感染に関する実態調查 患者の第 2 世代 $\mathrm{HCV}$ 抗体陽性率は $23.9 \%$ でり，当 然のことながら腎移植患者の HCV 抗体陽性率も高い ことが予想される。ささらに，腎移植後は継続して免疫 抑制剤を服用することから，そのような特殊な環境下 での HCV 感染と肝機能障害の関連性については興味 が持たれる．しかし，これまでのわが国での腎移植患 者の HCV 感染の実体については, 各移植施設が限ら れた症例数について検討しているに過ぎず2,3)，全国規 模で調査はこれまで行われてこなかった。

今回の調査の結果, 腎移植患者の第 2 世代 HCV 抗 体単独陽性率は $20.4 \%$ でり，血液透析患者の陽性率 が23.9\%であることを考えると妥当な数字と考えられ る.これを生体腎移植患者と死体腎移植患者に分けて
検討してみると，死体腎移植患者では陽性率が $29.6 \%$ と生体腎移植患者の $16.1 \%$ に比べ有意に高率であっ た．腎移植㭧者における HCV 感染に影響する因子と して, 移植前の輸血量と透析期間が指摘されてい $ろ^{2-4)}$. 今回の調查でも, 死体腎移植患者は生体腎移植 患者に比べ平均透析期間が長く，20単位以上の大量輸 血症例が多いことがその主な原因と考えられた (Table 2). しかし，一方では，HCV 抗体陽性者の約 $10 \%$ に輸血歴が認められなかった．透析以外の一般の $\mathrm{HCV}$ 抗体陽性者の約半数の感染経路は不明であ $\eta^{5)}, \mathrm{C}$ 型慢性肝炎患者と生活を共にする家族構成員 の HCV 関連抗体陽性者は $18.5 \%$ で，一般献血者より はるかに高率であったとの報告占や，同一透析施設内 でHCVのめずらしい genotype が複数例認められた ことから, 施設内感染を示唆する報告》もみられる.今 後はこのような輸血以外の感染経路についての検討が 重要になると思われる.

多くの報告3,8 10)が, HCV 抗体陽性者で腎移植後慢 性肝機能障害の発生が有意に高率であることを指摘し ているが, 移植後 10 年以上観察した報告9,10)でも，移植 堅生着率および患者生存率には差が認められていな い. 少なくとも HBs 抗原陽性者に比べると移植後肝 機能の推移は良好な経過をとるものが多く ${ }^{11}, \mathrm{HCV}$ 抗体陽性者の腎移植を禁忌と考える施設は少ないよう 
である.一方, HBs 抗原陽性者, 特に $\mathrm{HBe}$ 抗原陽性者 では,移植後重篤な肝機能障害が発生することがあり， HBs 抗原陽性者の腎移植を禁忌としている施設もあ る. 今回の検討では, $\mathrm{HCV}$ 抗体陽性者のうち移植後慢 性肝機能障害が47.2\%の症例に認められ，その頻度は $\mathrm{HBs}$ 抗原陽性者とほほ同程度であったが, 肝疾患によ る死亡頻度注有意に低率であり，HCV 感染者の腎移 植後臨床経過は HBs 抗原陽性者に比べると䋧徐な経 過をとる症例が多いように思われた。また，移植前に 肝機能障害を認めた症例では $66.7 \%$ と高率に移植後慢 性肝機能障害を認め, 多変量解析の結果でも移植前肝 機能障害の存在が移植後慢性肝機能障害発生の最も重 要な要因と考えられた. 確かに HCV 感染者の腎移植 後肝疾患は緩徐な経過をとる症例が多く，さらに，肝 移植の成績でも，移植後に HCV 陽性を示す症例の肝 疾患の進展は比較的緩徐とされている ${ }^{122}$. しかし一方 で, HCV 感染者で肝機能障害を有する慢性腎不全 患者に対する腎移植前の肝生検と抗ウイルス療法の必 要性も指摘されており ${ }^{13)}$ ，今後さらに検討する必要が あると思われる。

腎移植後肝機能障害の原因として免疫抑制绪の関与 も重要である ${ }^{3,4 !}$. そこで，免疫抑制剤の違いによって 移植後肝機能障害の発生頻度に差があるか検討した。 $\mathrm{Mz}$ は $\mathrm{Az}$ に比べ肝機能障害が少ない薬刜と考えられ ているが(14), 今回の調査結果では, $\mathrm{Az} と \mathrm{Mz}$ の違いに よる肝機能障害の発生頻度には有意差は認められな かった.

$\mathrm{CYA}$ も肝機能障害の原因となり得る薬版である が, CYA 投与群は非投与群に比べ明らかに移植後慢 性肝機能障害の発生率が低かった (Table 6).この最 大の理由は, 移植後観察期間の違いにあると思われた。 すなわち，移植後観察期間の平均は，CYA 投与群で 49.7カ月, 非投与群で134.7カ月と, CYA 投与群で有 意に短かった。さらに, 多変量解析の結果でも, CYA は腎移植後肝機能障害の発生に影響を及伊す独立した 要因としては抽出されなかった。しかし, CYAが肝再 生を促進するという実験結果の報告 ${ }^{15)}$, 原発性胆汁 性肝硬変やその他の自己兔疫性肝炎に対して少量の CYA と Prの投与が有効であったとの報告 ${ }^{16)}$ るら れ, CYA が腎移植後の慢性肝機能障害の発生防止に 役立っている可能性については，今後も検討する余地 が残されている.

今回の調査では，HCV 抗体陽性者に対する腎移植 はドナーが陰性の場合，29施設中25施設 $(86.2 \%)$ が
移植を実施すると答えている。これは先に述べたよう に,レシピエントが HCV 抗体陽性の場合, 移植後肝機 能障害の発生頻度は上昇するものの, 患者生存率拈よ び移植腎生着率が抗体陰性の場合と比べて差がないこ とが大きな理由と思われる。一方，抗体陽性ドナーか ら抗体陰性レシピエントへの移植については, 移植を 行うと答えた施設は 1 施設だけで，23施設（79.3\%） は移植に否定的であった. Tesi ら ${ }^{17}$ はCV 抗体陽性 ドナーから抗体陰性レシピエントへの繁移植43例を経 験し，移植後 $56 \%$ の症例で HCV-RNA が陽性となっ たが肝機能障害の発生は抗体陰性ドナーからの移植群 と差がなかったと報告している. Pereira ら ${ }^{18}$ は HCV 抗体陽性ドナーからの腎移植29例中 $96 \%$ が移植後 HCV-RNA が陽性で, $55 \%$ 症例に non-A, non-B 月f 炎の発症を認めたが, 抗体陰性ドナーからの移植群に 比べ, 移植後3.5年の時点では患者生存率および移植腎 生着率に差はなかったと報告している。移植後短期間 に肝機能障害が発生するか否かは別にしても, 移植蔵 器を介して HCV 感染が高率に起こることは事実の上 うである.わが国の肝細胞癌の.HBs 抗原陽性率が $17.8 \%$ であるのに対して，HCV 抗体陽性率は68.9\% と非常に高率であり，HCV 感染が肝細胞癌の最重要 因子と考えられている ${ }^{199}$.また, 翰血歴を有するC型 肝炎ウイルスによると思われる肝癌症例の検討では, 輸血から肝癌発生まての平均期間は $30 \pm 7$ 年と長期間 を要している20). 移植藏器を介した HCV 感染が, 免疫 抑制剤投与下という特殊な環境のもとで長期的にどの ような経過をとるかはあまりにも不明な点が多く，現 時点では HCV 抗体陽性ドナーから抗体陰性レシピエ ントへの移植は避けるべきと思われる。

今回の調查では, HCV 抗体陽性ドナーから抗体陽 性レシピエントへの移植については意見が分かれ, 約 半数 $(15 / 29,51.7 \%)$ の施設は賛成したが， 3 施設 (10.3\%) が反対，11施設 $(37.9 \%)$ が方針を決めか极 ていた。調查結果が示すように HCV 抗体陽性ドナー から抗体陽性レシピエントへの移植はより一層複雑な 問題を抱えている.HCV の genotype が違えば混合感 染の可能性があり，また genotype が同一であっても ウイルス量が増加する結果となる。これらのことが移 植患者の長期的予後に及ほ交影響について, 各施設が それぞれどのように判断しているかの違いが今回の調 查結果に表れていると思われる.

著者らの施設ては, 明らかな肝機能障害が認められ ない HCV 抗体陽性者であれば，仮にドナーが抗体陽 
性であっても移植を行ってよいのではないかと考えて いる. その理由梳, HCV 抗体陽性の慢性腎不全患者の 自然経過が腎移植を受けることによりどのように修飾 を受けるか明らかでなく，仮に多少の不利益が生ず るにしても，腎移植によって透析療法から解放される 利点の方がこれを上回ると考えるからである。この問 題に関しては今後さらに検討する必要があると思われ る.

な枋, 本研究㹥平成 5,6 年厚生科学研究費補助金腎不全 医療研究事業慢性腎不全医療に関寸る研究班 (班長, 三村信 英）の研究費により行った。

\section{文献}

1）秋葉 隆，川几良人，黑田満彦，他：日本の透析施 設における HCV 感染に関する奏態調查. 透析会 誌 $27: 77-82,1994$

2) 安村忠樹, 中井一郎, 吉村了勇, 他：腎移植患者に 括けるC型肝炎ウイルス感染, 透析会誌 27 : 1385-1389, 1994

3) Tomikawa S, Uchida $H, N a g o ~ T$, et al: Clinjcal implications of the presence of hepatitis $\mathrm{C}$ virus antibodies after kidney transplantation: Results of a satudy using second-generation assays for anti-HCV. Transplant Proc 26: 2023 $-2025,1994$

4) Morales JM, Munoz MA, Castellano G, et al : Impact of hepatitis $C$ in long-functioning renal transplants: A clinicopathological follow-up. Transplant Proc 25: 1450-1453, 1993

5) Alter MJ : Inapparent transmission of hepatitis $\mathrm{C}$ : Footprints in the sand (editorial). Hepatology $14: 389-391,1991$

6）田和良行：C型肝炎ウイルスの家族内感染に関す る検討. 肝臟 $35: 1-9,1994$

7) Corcoran GD, Brink NS, Millar CG, et al: Hepatitis $C$ virus infection in haemodialysis patients: A clinical and virological study. J Inf 28 : 279-285, 1994

8) Rohr MS, Lesniewski RR, Rubin CA, et aI : Risk of liver disease in HCV-seropositive kidney transplant recipients. Ann Surg 217 : 512517, 1993

9) Ranjan D, Burke G, Esquenazi V, et al: Factors affecting the ten-years outcome of human renal allografts. Transplantation 51 : 113-117, 1991

10) Ynares C, Johoson HK, Kerlin $T$, et al: Impact of pretransplant hepatitis $\mathrm{C}$ antibodies status upon long-term patient and renal allograft survival-A 5- and 10-year follow-up. Transplant ploc $25: 1466-1468,1993$

11) Stempel CA, Lake J, Kuo J, et al: Hepatitis $C$-its prevalence in end-stage renal failure patients and clinical course after kidney transplantation. Transplantation 55: 273-276, 1993

12) Shah G, Demetris AJ, Gavaler JS, et al : Incidence, prevalence, and clinical course of hepatitis $\mathrm{C}$ following liver transplantation. Gastroenterology $103: 323-329,1992$

13) Pol S. Romeo B, Zins B, et al: Hepatitis C virus $\mathrm{RNA}$ in anti-HCV positive hemodialyzed patients: Signicance and therapeutic implications. Kidney International $44: 1097-1100,1993$

14) Aso $K$, Uchida $H$, Yokota $K$, et al: Immunosuppression with low-dose cyclosporine combined with bredinine and prednisolone. Transplant. Proc 19: 1955-1958, 1987

15) Mazzaferro V, Porter KA. Scotti-Foglieni CL, et al: The hepatotrophic influence of cyclosporine. Surgery 107:533-539, 1990

16) Lie TS, Preissinger $H$, Bach $M$, et al: The protective effect of cyclosporine against cirrhotic alteration of the liver. Surgery $110: 847-$ 853,1991

17) Tesi RJ, Waller $K$, Morgan $C J$, et al : Transmission of hepatitis $\mathrm{C}$ by kidney transplantation-The risks. Transplantation $27: 826-831$, 1994

18) Pereira BJ, Wright TL, Schmid $\mathrm{CH}$, et al : A controlled study of hepatitis $\mathrm{C}$ transmission by organ transplantation. Lancet 25: $484-487$, 1995

19）日本肝癌研究会：原発性肝癌に関する追跡調查一 第11報一。肝歲 $36: 208-217,1995$

20）高瀬幸次郎，伊藤信康，為田䩗彦：慢性 C 型肝炎 の自然経過一長期予後を修飾する因子について 一. 肝葴 $36: 187-189,1995$ 


\title{
Clinical implication of the presence of hepatitis $\mathrm{C}$ virus antibodies after kidney transplantation in Japan
}

\author{
Shinji Tomikawa, Seiji Ito, Kenji KIKUChI, Yuichi Ando, \\ Naoya IchIKaWA, Kazuhiko MeIgata, Kenshi Watanabe, \\ Yoshifumi Beck, Hisakazu DEGAWA, Takeshi NAGAO \\ and Hisanori UCHIDA*
}

The purpose of this study was to determine the clinical implication of the presence of hepatitis $\mathrm{C}$ virus (HCV) antibodies in kidney transplant patients in Japan. A questionnaire on $\mathrm{HCV}$ infection estimated by the second-generation antibodies was sent to the transplant centers performing the most kidney transplants in Japan. Of 1,405 transplant patients, 287 (20.4\%) were anti-HCV positive, and the number of anti-HCV positive transplants from cadaver donor and those from living donor were $134 / 453(29.6 \%)$ and $153 / 952(16.1 \%)$, respectively $(\mathrm{p}<0.01)$. Of 287 anti-HCV positive patients, 250 were possible to evaluate the liver function before and after kidney transplantation, and chronic liver dysfunction (CLD; serum GPT $>50 \mathrm{IU} / l$ for over 3 months) developed $118 / 250$ (47.2\%). Multivariate analysis identified LD before transplantation, duration of follow-up and volume of blood transfusion as risk factors for developing of LD after kidney transplantation. Most respondents $(23 / 29=79.3 \%)$ stated that they do not use the kidneys from anti-HCV positive donors into anti-HCV negative recipients.

* Department of Surgery and Oragan Transplantation, Institute of Medical Science, University of Tokyo (Tokyo) 